\title{
Kathy Foley
}

\author{
Margaret J. Coldiron
}

\begin{abstract}
Kathy Foley is a distinguished scholar, performer, and director based at the University of California, Santa Cruz, and she has also taught at the University of Hawai'i, Chulalonkorn University, Yonsei University, and the University of Malaya. A specialist in wayang golek puppetry of Sunda (West Java), she has also published widely on a diverse range of performance forms from all over Southeast Asia as well as India, Tibet, Japan, and Korea. She has written and directed plays and operas and curated exhibitions of masks, puppets, and performing objects and has been the editor of Asian Theatre Journal since 2005.

Margaret Coldiron is a specialist in Asian performance and masks, and deputy head of the BA in world performance at East 15 Acting School/University of Essex. She is the author of Trance and Transformation of the Actor in Japanese Noh and Balinese Masked Dance Drama (Mellen Press 2004), is a contributor to The Routledge Handbook of Asian Theatre (2016), and has published numerous articles and reviews in journals such as Asian Theatre Journal, New Theatre Quarterly, Indonesia and the Malay World, and Consciousness, Literature, and the Arts. She is the associate director of Thiasos Theatre, specializing in intercultural productions of ancient Greek plays; performs Balinese topeng with Lila Bhawa Indonesian Dance Company; and plays with Gamelan Lila Cita in London.
\end{abstract}

Mary Kathleen Foley (b. 1947) was born in Waukegan, Illinois. She finished her undergraduate degree in English at Rosemont College, a small Catholic women's school, completing sixteen years in schools run by Holy Child nuns. This is not, perhaps, the background one expects for a dalang of Sundanese wayang golek or Southeast Asian performing arts, though it may explain an interest in ritual and religion seen in some of her work.

Foley, who had always wanted to be an actor, participated in theatre as an extracurricular activity in high school and college and 
did summer stock, as theatre and dance were not offered as formal classes in any of the Catholic schools she attended. She received a BA in English literature and accepted a Fulbright grant to study Germanistik at Ruhr-Universitat Bochum and Freiburg in 1970-1971, where for the first time professional theatre was regularly accessible to her. She hitchhiked overland to India, traveling six months in India an dseeing a wide variety of dance and traditional forms, which had "liveness"-with interactive audiences, musicians, dance, and storytelling that happened in the same piece, sometimes in the context of temple festivals. One could see Brecht "alive and well" in Marxist-inflected Calcutta of 1972.

She entered the then recently established DFA program at the Yale School of Drama. She was restive with the largely text focus and psychologically centered interpretive approaches in the program, but took the opportunity to work with Jacques Burdick in a mime workshop, and that led her toward a summer course taught by Jacques Lecoq at Harvard. This French lineage of Copeau theatre training seemed potentially connected with Indian viewing. She left Yale to spend six months as a Red Cross "Donut Dolly," a job born in the wake of World War II that extended to the Vietnam era and sent young American women to do recreation programming for military units near conflict zones (Fig. 1; see Cassier 2014). By the 1970s this meant posts in either Vietnam or Korea. She worked at Camp Casey near the Korean DMZ doing the weekly radio programing and taking helicopter rides to hill stations to present entertainment, games, and programs to GIs, greeting them with "Hi, I'm your Second Division Red Cross Donut Dolly!" And, yes, she passed out donuts, too. Foley's experience here in some ways parallels a number of the figures who founded Asian theatre studies in the United States, who were exposed to Japanese theatre as GIs in the wake of World War II or the Korean war.

During this period she was exposed to aspects of Korean shamanism in the villages, the then expansive theatre of "war games" manuvers at the DMZ, and various Korean performance genres. In time these would lead to some writing (Foley 2014a), performance, and exhibit work on Korean performing object or themes. During this sojourn she first visited Indonesia and was drawn to the mixture of music, dance, ritual, and event that made up performances during Balinese temple festivals, seeing her first wayang parwa shadow show. She noted the friendliness toward outsiders (Foley 2014b). Entering a master's program at the University of Massachusetts at Amherst in 1973, she led a commedia dell'arte troupe that devised performance for the village greens in the Five College area, tapping her modest training with Burdick and Lecoq as a base. 
During the summer of 1974, she attended the Center for World Music's (CWM) summer school at Berkeley, studying Balinese wayang kulit with Dalang I Nyoman Sumandhi (alongside fellow dalang Fredrik "Frits" deBoer [see Foley 2011b]) and wayang golek purwa sunda rod puppets with Dalang Rudjita Soehyapoetra, a skilled carver from the Sundanese region of West Java who had come for the summer. Additionally, she learned Korean dance with Hi-yah Park, who was starting to branch from traditional dance into her private practice of shamanism for the West, and Balinese dance with I Nyoman Wenten, who has continued to teach at Cal Arts and UCLA.

At CWM one could see Indian bharata natyam prima donna Balasaraswati and her brothers perform one night and Central Javanese master KRT Wasitodipuro's gamelan students accompanying his daughter, Nanik Wenten, with her advanced students presenting a srimpi (refined female palace dance) the next evening. At the end of the summer Sumandhi tapped her to perform as the "First Balinese Female Dalang" for a student concert. Sumandhi later claimed that he conceived the idea to encourage his niece (and, subsequently, other

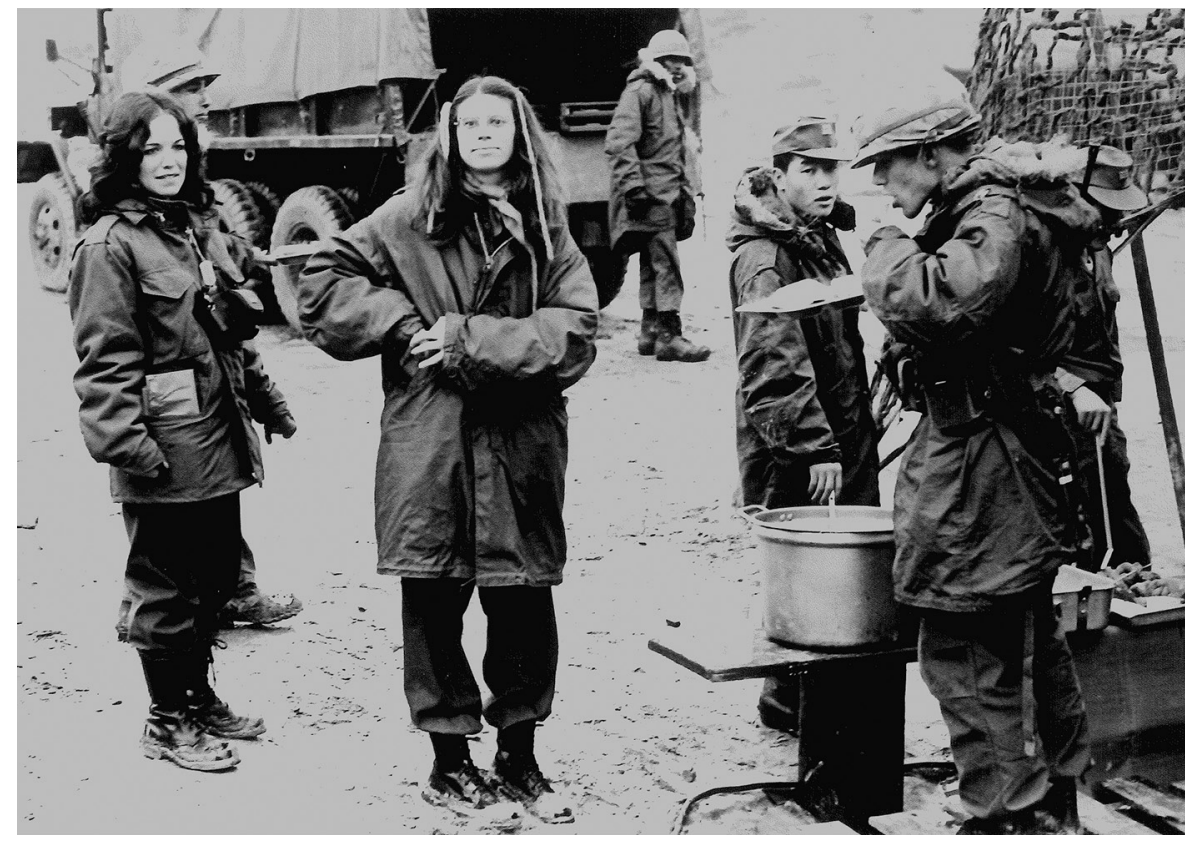

Figure 1. Kathy Foley (center) with Merrily Locke (left) as "Donut Dollies" doing a recreation programming near the DMZ in 1973 during a "war games" exercise by the 2nd Division of the US Army and the Republic of Korea forces. (Photo: Courtesy of Kathy Foley) 
women) to become the first actual Balinese female dalangs from his experience of teaching women like Foley and Lisa Gold at CWM during the summer of 1974. Philanthropist Samuel Scripps, however, shortly thereafter withdrew his funding support for this amazing program that helped launch figures like John Emigh (see Foley 2011c), Julie Taymor, Larry Reed, and many others into diverse experiments in intercultural theatre with Asian connections. Many from the CWM cohort have engaged in lifelong pursuit of various Indonesian and Indian styles of music, dance, and theatre as a result of the exposure and they have impacted ethnomusicology, dance ethnology, and Asian theatre studies in the United States. Wayang experiences at CWM led her to apply to the University of Hawai' $i$, with its unique practice-based Asian theatre program, and she took up doctoral studies with support from the EastWest Center: "Asian theatre was the only way I would envision a PhD. I wanted to find actor-centered theatre, improvisational theatre, theatre of music, objects-not 'prop and word' dominated stuff. I was looking for a world with the performer at the center and found it in wayang" (Foley 2015b).

Foley worked under James Brandon, who was at that time one of few in theatre (as opposed to Southeast Asian studies, music, or anthropology) writing on Javanese wayang kulit as performance. ${ }^{1}$ She collaborated with Brandon on his modern kabuki play, The Road to Kyoto (1977), before embarking on fifteen months of fieldwork in rural West Java that led to her dissertation, "The Sundanese Wayang Golek: The Rod Puppet Theatre of West Java” (Foley 1979). Before Foley's work there was very minimal existing Western scholarship about this active and popular puppet theatre apart from a brief article in the Dutch journal and a limited treatment in Tyra de Kleen's Wayang: Javanese Theatre (1947): most Westerners to the present have focused performance research on Javanese and Balinese traditions; thus research on other areas is comparatively limited. As well as training in mask dance and as a dalang (intimately related arts), she studied the small but growing collection of Sundanese- and Indonesian-language publications about the performance methodologies, techniques, and literature of wayang golek. While these materials, coming out of the Bandung arts schools-the Indonesian High School of Music (SMKI) and the Academy of Performing Arts (ASTI) - were useful for comparison, Foley recognized their limitations. Materials were largely written by academics with higher degrees from Central Javanese institutions, which in that period inculcated locals in a mission of "correcting" non-Javanese versions of wayang or other arts and attempting to replace village versions of stories, music, mantra, with Central Javanese court versions. For example, though there was no real con- 
cept of pathet (musical mode) in Sundanes wayang, authors wrote as if there were. This discrepancy was both a class-based academic dynamic and a Javanese tendency that comes of the court-centered feeling that other ethnic groups and lower classes "do not do it right." Hence, Javanese theory represented in scholarship was frequently at odds with Sundanese practice: "Rather than simple documentation of the art as it is practiced in Sunda, there is a tendency to look to Central Java for models and corrections. [. . . They [academics at the institutions of higher learning] produce the work to educate dalang, but the impact of these works on dalang is still rather slight. [...] To this day the dalang of Sunda rely on what they have learned orally from their teachers" (Foley 1979: 12-13).

Foley documented wayang golek as it was practiced in villages and in cities, on radio and on television. She watched hundreds of performances, interviewed the puppet masters, and studied the art both in formal lessons and in the traditional manner by following her gurus (Dalang Abeng Sunarya and Dalang Otong Rasta) and living with the former's family. "I joined the group of Asep Sunandar Sunarya [son of her teacher and soon to be a superstar master dalang] and I soon found myself well known and obligated to sing a rather off-key "Warung Pojok" [Cafe at the Corner] song every night, and then a pseudo "Hawaiian" chant-they felt I was Hawaiian since I studied [at the University of Hawai'i]" (Foley 2014b). The dissertation that emerged from this work is regarded by scholars in the field the most important document on the subject in English, though other books have documented the visual aspects (Buurman 1988), musical changes (Weintraub 2004), and anthropological implications (Andrieu 2014). It is detailed, accessible, and passionate-qualities that have persisted in Foley's subsequent scholarly work.

In a comprehensive and moving article on the wayang kulit specialist Roger Long, Foley said: "Many of us who take on Indonesian wayang find the demands of fundamental research in this genre daunting. To fully master the genre one must be a consummate musician, a great dancer, an expert on the story repertoire, a philosopher, and a thinker of scope" (Foley 2011d: 471). Kathy Foley's career demonstrates that she has not only managed to take on all these elements of the dalang's art $^{2}$ but many more besides. In addition to a broad repertoire of wayang golek performance (Fig. 2), she is widely versed in other puppet and mask performance from a diverse range of cultures. She has a deep understanding of the spiritual and cosmological underpinnings of much of Asian traditional performance practice and has found ways to share and disseminate her knowledge as a performer, teacher, and scholar through a variety of means, from work in primary school 
classrooms to museum exhibitions, stage performances, and academic symposia.

In 1980 Foley began teaching in the Theatre Arts Department at the University of California at Santa Cruz, a campus then known for its innovative approach to education and for its bohemianism. She has served as a provost at Porter College (with focus on the arts), Merrill College (social sciences and non-Western materials), and Kresge College (literary studies and community). She has used her skills and her international connections to contribute to the cultural life of the campus and to the community beyond. From her arrival at UCSC she was involved in the Artists-in-Schools program, taking her wayang performances and gamelan (with colleague Undang Sumarna) into schools and promoting cross-cultural understanding in the increasingly multicultural environment in and around Santa Cruz. When the Arts Bridge program began in 1996 to send UCSC students into local K-12 schools to teach arts, she got her students involved in this work, promoting arts education among kindergarten through high school students. For example, her student Ben Arcangel, who later went on to be named

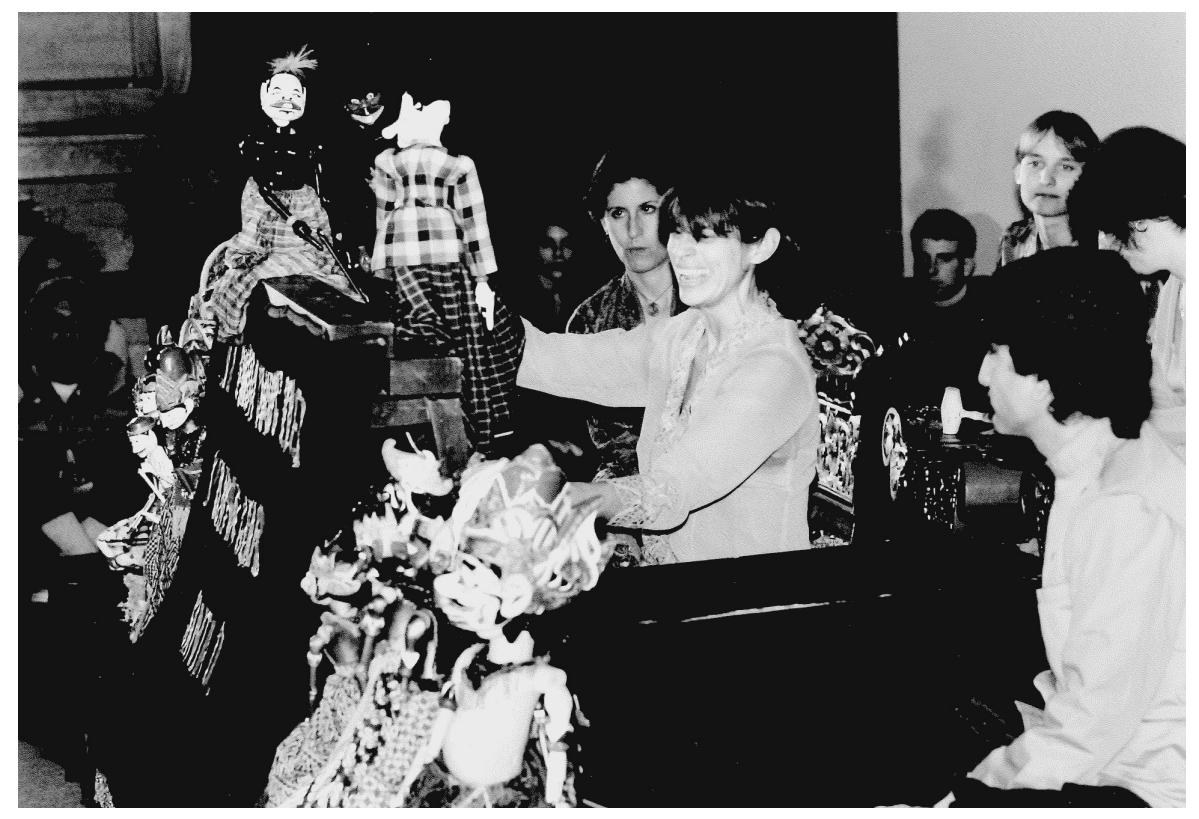

Figure 2. Kathy Foley (enter) performs wayang golek sunda with the clown Semar (light face and black body) and his sons (Astrajingga behind Semar and Petruk facing him). Her puppetry graduate students Michael Schuster (foreground) and Shae Uisna (behind Foley) assist along with UCSC gamelan players. (Photo: Courtesy of Kathy Foley) 
best dancer at the American College Dance Festival for his performance of wayang-style dance, taught gamelan and Sundanese dance in a local grade school (see Foley 2005).

\section{Performing as Dalang-Director}

Although Foley has remained associated with a single institution throughout her career, this does not mean that she has stayed put. She has continued to perform as a dancer, actress, and dalang throughout the region and internationally, and she was the first non-Indonesian to be invited to perform at the Indonesia National Wayang Festival in the 1980s (and she suggested that two other dalang, Marc Hoffman and Larry Reed, also be invited). She has also taken residencies and visiting posts at the University of Hawai'i (1985), Chulalongkorn University in Thailand (2003-2007), Yonsei University in Korea (2007), and the University of Malaya $(2011,2014)$. She held a fellowship at the Yale Institute of Sacred Music (2012-2013) and been supported by groups like the Asian Cultural Council (most recently in 2016), Fulbright $(2003,2014)$, the Soros Foundation, and others. She has done regular productions of wayang wong (Indonesian dance drama) with casts of up to forty students, taking on themes from the Mahabharata: Before the Great War (1997), Ramayana (1993, 2001, 2015) (Fig. 3), and other standard Indonesian stories, including the tale of the Islamic

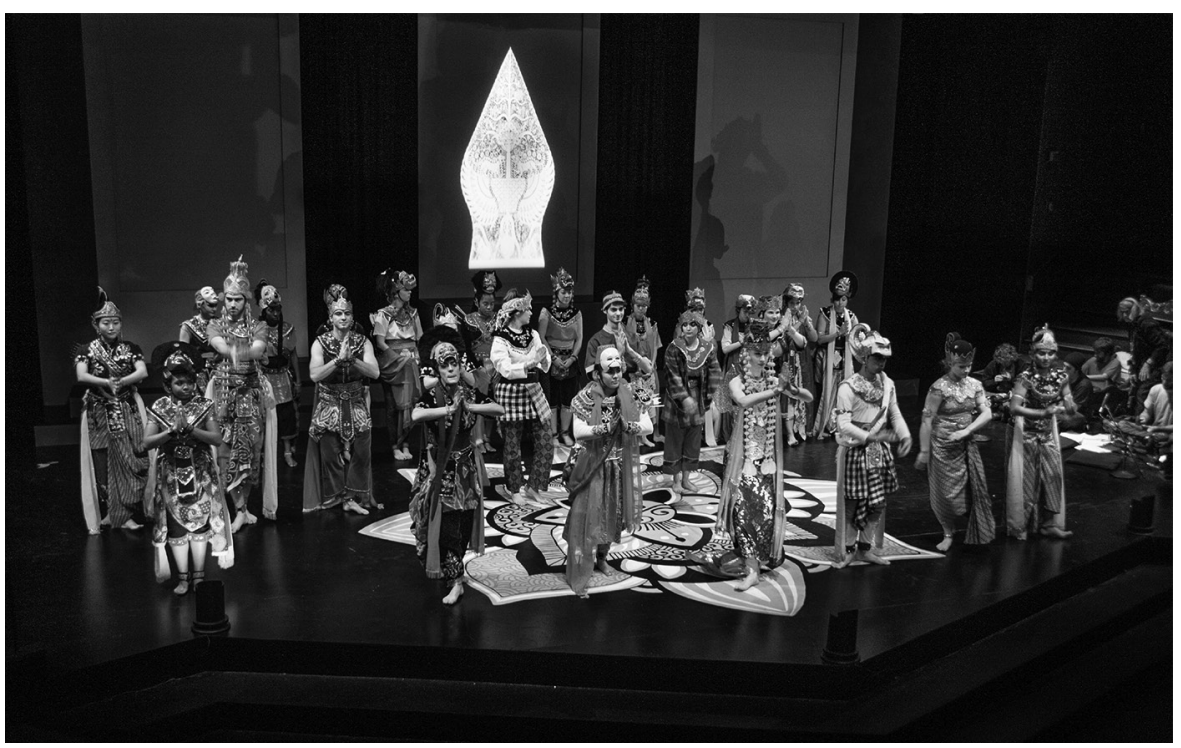

Figure 3. Curtain call of Ramayana: Of Monkeys and Men (2015) at University of California Santa Cruz. (Photo: Courtesy of Kathy Foley) 
saint Sunan Kalijaga, who is said to have invented wayang, mask dance, and the other arts to convert people to Islam in the fifteenth century. The production of Ghostly Goddess and the Sinner Saint: How Islam Came to Java (2003) was a collaboration with noted Balinese legong dancer Bulan Jelantik and Irawati Durban Arjo from Bandung and responded to the post-2001 Islamophobia as well as the fundamentalist aspects of the Islamic revival in Indonesia that had begun to question the arts.

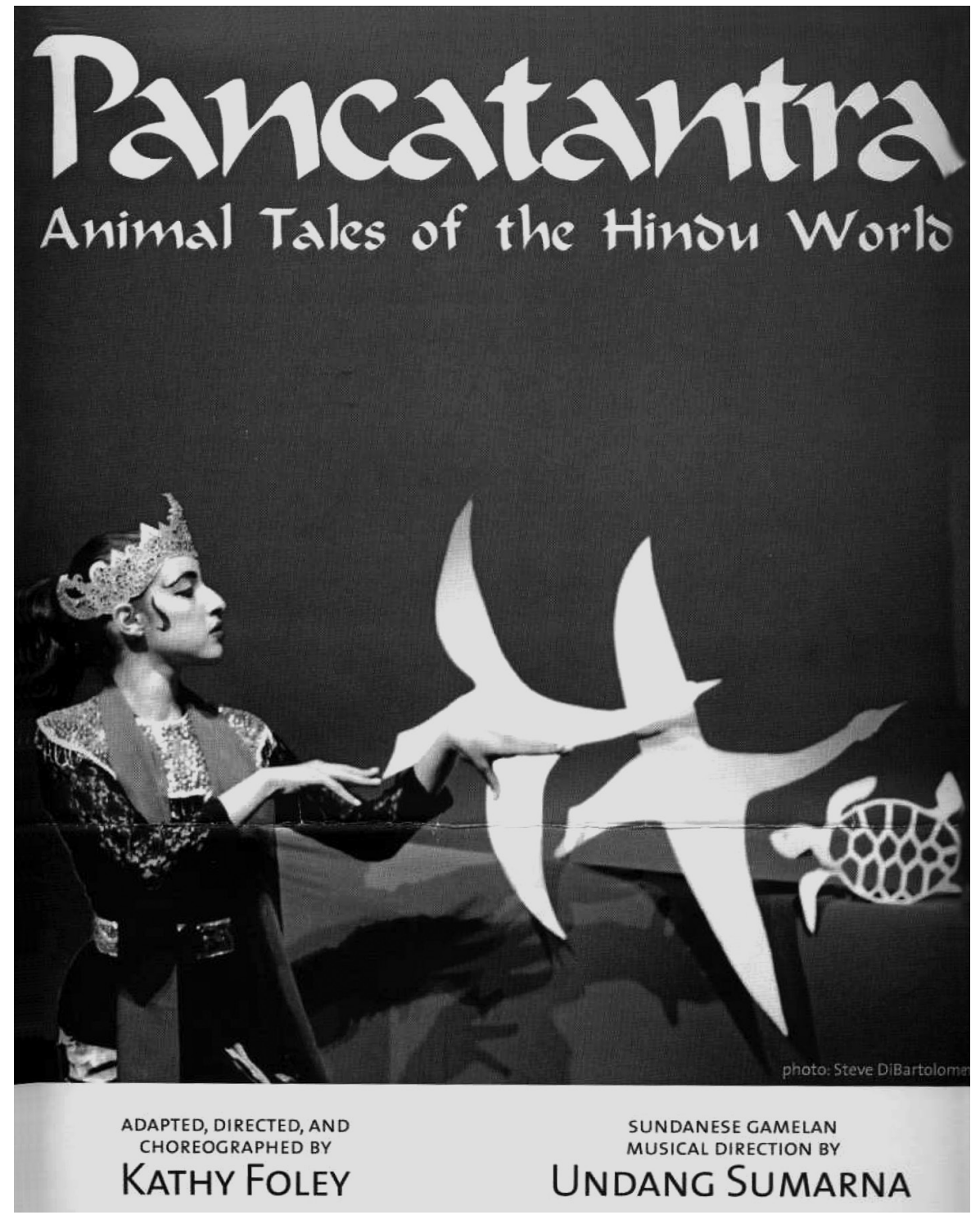

Figure 4. Poster for Pancatantra (2002). (Courtesy of Kathy Foley) 


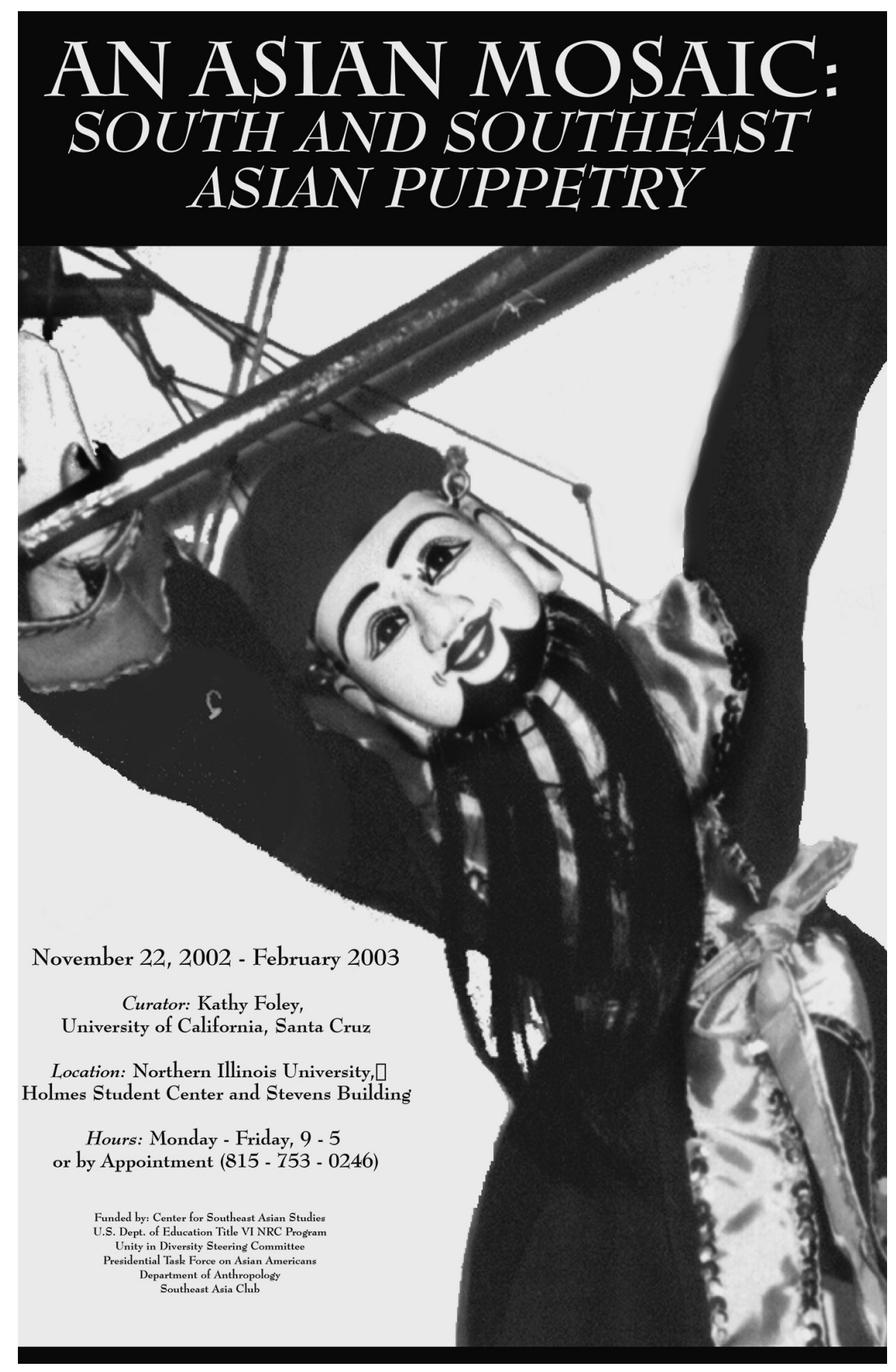

FIgURE 5. Foley leads a performance class at the University of Malaya during a Fulbright Senior Scholar grant in 2014. Students rehearse the wilderness scene from the Layla and Majnun story in Mughal Miniatures. (Courtesy of Kathy Foley) 
Foley has also done major performances that adapt other nonIndonesian materials into wayang-like structures: Pancatantra (2002; Fig. 4) was based on Indian versions of animal tales rather than the Indonesian Tantri stories that tell similar tales. It toured to schools.

Before Becoming Buddha: Jataka Tales of the Buddha's Previous Lives (2007) told of the Buddha in various incarnations including as a tree, monkey, and even Rama (in a segment using Thai nang yai large leather puppets, dance movement, and drumming), and, of course, the play presented Vessantara (the final life before Gautama's birth as the historical Buddha), with this latter episode presented using Burmese marionettes (yokthe thay). Mughal Miniatures (2013) used Indian dance and music to tell the love stories of Shiran and Khosraw and Lalya and Majnun (borrowing from Nizami versions) (Fig. 5) as well as the Gita Govinda tale of Radha and Krishna. Her collaborations are normally undertaken with Undang Sumarna, grandson of the important Sundanese drum master Pak Kandeg. Sumarna teaches in the music department at UCSC. In many of the productions, important exponents of Sundanese arts have participated, including Enoch Atmadibarata (the great documenter of the arts of West Java), Endo Suanda (an important exponent of Cirebon area arts), and so on; probably the most significant artist has been Irawati Durban Arjo, who emerged as a star Sundanese dancer in the 1960s, touring throughout the world on cultural missions for the Sukarno and later the Suharto government. The collaboration of Irawati, Undang, and Foley has allowed students to understand the interrelationship of music, dance, puppet, mask, and culture. The UCSC group toured through West Java in 1989 with support from the West Java government and has been invited back for other events. Students involved in such projects now teach ethnomusicology and Indonesian politics, run educational outreach for Southeast Asian Studies programs, or are professional actors and puppeteers.

Foley has contributed to intercultural performance beyond wayang. She wrote and performed in Shattering the Silence, along with and Patty Gallagher and Avanti Meduri, about three trailblazing women (Madame Blavatsky, Annie Besant, and Rukmini Devi) who helped create the Theosophical Society around the turn of the twentieth century; their stories spanned the globe, and the play toured campuses throughout the United Kingdom, as well as Brown University (2003-2005). More recently she collaborated with the noted pansori performer Chan Eun Park on Fox Hunts and Freedom Fighters, about the "intertwined lives" of Queen Min, the Korean monarch, and Isabella Bird Bishop. Bird Bishop while traveling in Korea was the Queen Min's doctor and friend in the period before the queen was assassinated by the Japanese in 1895. This piece, using china-headed dolls, also told the history of 
Ryu Gwansun, the Korean "Joan of Arc" and her American missionary teacher at the school for girls, which has now become Ewha University. Gwansun protests against Japanese colonialism lead to death in the aftermath of the 1919 independence movement. This play interrogating Korean-Western relations played at Theatre of Yûgen (2009), Yale University, and East-West Center in Hawai'i (2011). It combined pansori-style narration and puppetry.

Foley has written or cowritten more than a dozen plays and opera liberetti, which have been performed in a variety of venues from Santa Cruz to Yogyakarta. She has also directed many productions of plays with her Santa Cruz students, with local schools, and with students and professionals in Asia. The productions range from mainstream European classics like Chekhov's Cherry Orchard (1999) to classics of the Asian repertoire like Sakuntala (1982) to her own works. These include her adaptation of Japanese American Jeanne Wakatsuki Houston's life story in the play of Farewell to Manzanar (1997). Houston was interned in the World War II Japanese concentration camp at Manzanar, California. Foley added to Houston's tale the oral history of her sansei (thirdgeneration Japanese American) niece, who helped organize the 1980s political movement for reparations to survivor-citizens who like Houston were imprisoned without cause in 1942. The production incorporated aspects of $n \bar{o}$ as a contemporary waki traveler character meets a ghost (shite wearing a mask) at the wind-blown site of Manzanar concentration camp. The sansei generation's search for justice was modeled in part on the vendetta of masterless samurai in Chushingura: Treasury of Loyal Retainers. But these ronin were the sansei lawyers whose concerted political efforts achieved revenge. Bunraku-style figures and nō masks represented the issei generation and contrasted with the second generation of actors and American toy figures (Barbie dolls for Houston's triumph as prom queen and GI Joes for the devastating losses by the 442nd All-Japanese American division). The Japanese American community invited the production to play at local Buddhist temples and the retreat at Thule Lake (site of an internment camp) as part of education about this history that was for many years suppressed.

\section{Scholarship}

As a specialist in Sundanese puppet theatre of West Java it is not surprising that Foley has published on puppetry of all kinds and on mask performance, but her scholarly work goes far beyond that. She has written with deep understanding about acting and acting techniques, comparing Western psychological realism to the "empty vessel" kinesthetic methods of Southeast Asia. She has written about trance performances, and, most of all, she has written a great deal about the 
importance of understanding cosmology and spirituality in order to better understand Southeast Asian performing arts. Some more recent writing has addressed issues surrounding the politics of UNESCO's Intangible Cultural Heritage designations (Foley 2014c). She has also contributed great swaths of material for various reference works, such as The Cambridge Guide to Asian Theatre (Brandon 1997), Encyclopedia of Asian Theatre (Leiter 2007), The World Encyclopedia of Puppet Arts (Foulc 2009, in French), and even more in the latter's revised English version, which is scheduled to appear online at the UNIMA website. Her translations have been published in anthologies of modern of Indonesian plays. ${ }^{3}$

Foley's articles address diverse materials, including, among others, Japanese kumi odori (udui) (Foley and Ochner 2005); female representation (Foley 1988); Vietnamese water puppetry (Foley 2001); Tibetan lhamo (Foley and Karter 1988); Malay theatre (Foley and Sabzali 2012; Foley 2015d), intercultural theatre (Foley 1988; 1992a); cultural heritage issues (Foley 2014b; 2014c); and, of course, essays on Indonesian arts (Foley 1979; 1984; 1985; 1987; 1990; 1992b; 2015a; 2016; Foley and Sedana 2005; Foley, Kodi, et al. 2005; all entries on Southeast Asia traditional theatre in Brandon 1997).

She has also created and curated a wide range of exhibitions, mainly related to Asian puppets and masks on South Asian, Southeast Asian, and Korean themes in a variety of venues: Yale University (2014); the Northern Illinois Museum of Anthropology (2002 [Fig. 6], 2005, 2011); the East-West Center in Hawai'i (2001, 2005, 2012, 2016); the National Geographic Society (1991), and the Atlanta Center for Puppetry Arts (1990-1991, 2000-2001, 2006-2007) and other sites (see Clark 2005 for a sample review). In 2015 her exhibit on Malaysian mak yong and wayang kelantan took on the issues of these arts that have, since the 1990s, been largely banned in their home state of Kelantan as a result of the fundamentalist strain in the Islamic revival. This means these arts, which are nationally or internationally recognized as intangible heritage arts (for example, mak yong received its UNESCO designation in 2005), are endangered species on their home ground. Foley is currently developing a 2017 Indian puppet exhibit for the Center for Puppetry Arts in Atlanta that will include the work of contemporary innovators as well as the traditional forms that make up the bulk of the museum collection, and another on Thai nang talung, a genre that like wayang kelantan has been impacted negatively by Islamic fundamentalism, competition from modern media, and the difficulties of existing in an area where Thai government suppression and Islamic resistance have made fighting routine. Because Foley is herself a performer, the focus of these exhibitions is on the figures as performing objects, rather 


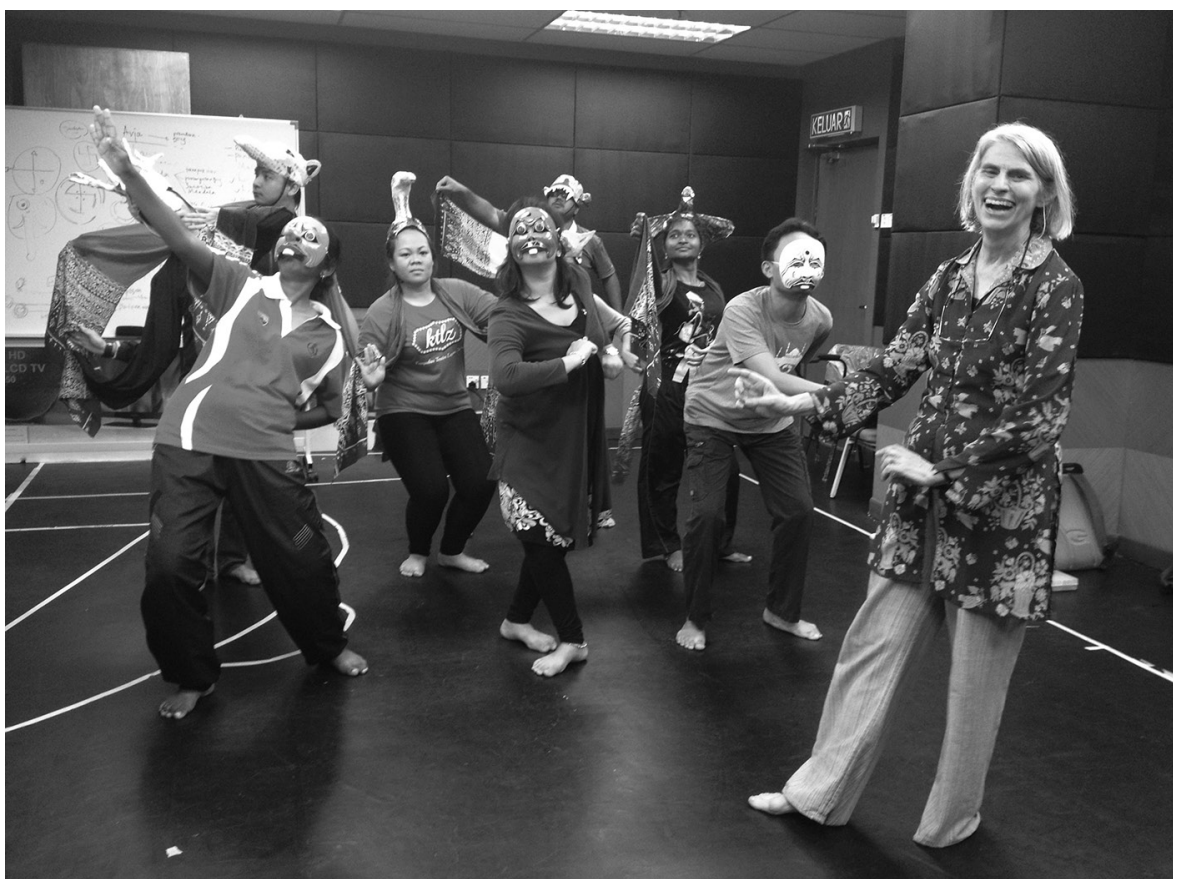

Figure 6 . Foley has curated many exhibits. This poster for this 2002 display at the Northern Illinois University Museum of Anthropology features the Alchemist character of Burmese yothe pwe marionettes. (Courtesy of Kathy Foley)

than merely noting their aesthetic beauty, antiquity, or exotic qualities. In conjunction with these exhibitions she presents seminars, demonstrations, and performances-bringing the objects alive for museum audiences who might not otherwise have encountered these characters in performance. She has also elaborated on connections of Asian traditions to forms like commedia dell'arte in writing (Foley 2015a), linking back to where her work with the mask began.

\section{Editor and Enabler}

In an article published in the very first issue of Asian Theatre Journal, titled "Of Dalang and Dukun-Spirits and Men: Curing and Performance in the Wayang of West Java," Foley quotes her guru Dalang Abeng Sunarya, who outlined the ideal responsibilities of the dalang: " A dalang should help the needy, help those in difficulty, give, accompany the fearful, help up the fallen, save the drowning, feed the hungry.'. Those who do so are considered the dalang kandabuana (kanda, 'book'; buana, 'world'): dalang who can explicate the meaning of life" (Foley 1984: 55). 
In her life and work as a teacher, scholar, performer, and editor, it is apparent that Foley has taken these words to heart, and one of the most significant, yet almost invisible, aspects of her work has been the support she has given to other scholars, to emerging scholars, and especially to Asian scholars and performers, helping them to develop their work and writing and to publish on an international level.

One such example is Balinese performer I Nyoman Sedana, who both studied and taught gamelan on an exchange program at UCSC, then started a master's degree at Brown University in 1991. During that year in residence he also started teaching classes in Balinese performance and joined her performances doing wayang in schools. Sedana credits Foley with helping him to organize and articulate his ideas as he worked on his master's thesis and then $\mathrm{PhD}$ at the University of Georgia. She helped edit his grants, which needed to be submitted in English, and papers for international journals as he launched his career. Because of Foley's support, Sedana, a village boy from a humble background, was able to secure a tenured position at Insitut Seni Indonesia-Denpasar ${ }^{4}$ and rise to the rank of full professor. Now established as a distinguished performer and teacher working internationally, he still regards Kathy Foley as a mentor, and they occasionally still collaborate: "Last time [I worked with her] she served as the dalang narrator for our sendratari [dance drama] Rajapala at Yale University [2013]. I was always happy [when studying in Santa Cruz in the 1990s] to help her wayang golek performances in any way I could. She always gives me scholarship directions and guidance that I simply follow, because her directions were right and thoughtful" (Sedana 2014).

There are dozens of scholars who have benefitted from Kathy Foley's encouragement, editorial support, and supervision from experienced senior researchers to early stage graduate students. Because UCSC has only recently begun a graduate program, much of her work with graduate students has been serving on $\mathrm{PhD}$ committees for UC Berkeley or Stanford, MFAs in digital arts or education at UCSC, or others who are doing their work in different institutions. She feels that her editorial work has provided the means by which she can further engage in teaching at graduate and postgraduate level. "My interactions with graduate work [in ATJ editing] are mostly through helping people to understand how to make their good research more accessible to a wider audience and how to make the transition from writing for their professor, who knows their material, toward writing for a wider audience" (Foley 2015b). This has been most evident in her work on the Emerging Scholars panel for the Association for Asian Performance conference. Since taking over as editor of the Asian Theatre Journal in 2004 following the editorship 
of Samuel Leiter, Foley has served on the review committee. When the most promising papers have been chosen, she works closely with the authors to revise the work, and even for those papers that are not perhaps so fully developed, she provides detailed feedback and encouragement to resubmit.

Former Emerging Scholar Emily Wilcox, now an officer in the Association for Asian Performance, commented:

Kathy is an amazingly dedicated editor who always seems to be thinking and caring about how to nurture the work of young scholars. In my first interaction with Kathy, I submitted an embarrassingly long, unedited, dissertation chapter to ATJ for consideration as an article. Kathy wrote back with comments that somehow managed to be both tremendously encouraging and usefully stern. She encouraged me to edit the paper and resubmit it for the Emerging Scholars Panel. At the time I had never heard of AAP [Association for Asian Performance], and this ended up being an important turning point on multiple levels. She welcomed me to a community of scholars I could call home. Since then, I have always been amazed at how quickly and thoroughly Kathy responds to emails, returns edited drafts, and responds to concerns on the AAP board. Behind the scenes, she is a huge part of what makes AAP flourish as an organization and a producer of new scholarly knowledge in our field. (Wilcox 2015)

What distinguishes the "founders of the field" of Asian performance is that they are, in the main, remarkable individuals who are able to combine meticulous and detailed scholarship with practical expertise as theatre makers in their field and make this work accessible to students, scholars, and the general public. Because of individuals like Kathy Foley and the other founders of our field, the understanding and appreciation of Asian performance in the West has moved from the periphery to the mainstream. Kathy Foley's work as a teacher, performer, editor, and scholar continues to play a significant part in this.

\section{NOTES}

1. See discussion of Jim Brandon work as a founder of the field of Asian theatre studies in American higher education in Jortner and Foley (2011).

2. For examples of her performance, see recording of a 2014 presentation at the Freer/Sackler Gallery of the Smithsonian Institution (https:// www.youtube.com/watch?v=xDiH8ktqZu8, accessed 27 June 2015). For a sample of lecture materials on wayang, see the San Francisco Asian Art Museum's short video "Indonesian Puppets Wayang Golek" (https://www.youtube .com/watch?v=Wph0cBNi7Yo, accessed 27 June 2015). 
3. For her translation of Saini K. M.'s work, see Foley (2011a). For a play of Ratna Sarumpaet, see Foley (2015c).

4. Institut Seni Indonesia Denpasar is a university-level school of fine, visual, and performing arts that grants undergraduate and postgraduate degrees, part of a national system of such institutions in regional capitals throughout Indonesia.

\section{REFERENCES}

Andrieu, Sarah Anaïs. 2014.

Corps de bois, souffle humain: Le théâtre de marionnettes wayang golek de Java Ouest. (Wooden Bodies, Human Breath: Wayang Golek Puppet Theatre of West Java). Rennes: Presse universitaires.

Brandon, James, ed. 1997.

The Cambridge Guide to Asian Theatre. Cambridge: Cambridge University Press.

Buurman, Peter. 1988.

Wayang Golek: The Entrancing World of Classical Javanese Puppet Theatre. Singapore: Oxford University Press.

Cassier, Ellysa. 2014.

"The Donut Dolly: A Girl-Next-Door's Experience of Vietnam." Iowa Historical Review 4, no. 2: 5-41.

Clark, Bradford. 2005.

"Divinities, Demons, Kings, and Clowns: Puppetry of India and Southeast Asia by Kathy Foley; Michael Schuster" [Review]. Asian Theatre Journal 22, no. 1: 164-168.

de Kleen, Tyra. 1947.

Wayang: Javanese Theatre, 2nd ed. Stockholm: Gothica.

Foley, Kathy. 1979.

"The Sundanese Wayang Golek: The Rod Puppet Theatre of West Java." PhD dissertation, University of Hawai'i, Mānoa. 1984.

"Of Dalang and Dukun —Spirits and Men: Curing and Performance in the Wayang of West Java." Asian Theatre Journal 1, no.1: 52-75. 1985.

"The Dancer and the Danced: Trance Dance and Theatrical Performance in West Java." Asian Theatre Journal 2, no. 1: 28-49. 1987.

"The Tree of Life in Transition: Images of Resource Management in Indonesian Theatre." Crossroads: An Interdisciplinary Journal of Southeast Asian Studies 3, no. 2/3: 66-77.

1988.

"Hanako and the European Imagination." Asian Theatre Journal 5, no. 1: 75-85.

1990.

"My Bodies: The Performer in West Java." TDR 34, no. 2: 62-80. 
1992a.

"Artaud, Spies and Indonesian/American Artistic Exchange and Collaboration." Modern Drama 35, no. 1: 10-19.

, ed. 1992b.

Essays on Southeast Asian Performing Arts: Local Manifestations and CrossCultural Implications. Berkeley: University of California Center for Southeast Asia Studies.

2001.

"The Metonymy of Art: Vietnamese Water Puppetry as a Representation of Modern Vietnam.” TDR, 45, no. 4: 129-141.

2005.

"Wayang and Gamelan as a Tool of Cultural Leaning: Indonesian Puppets, Dance and Music in the Classroom," Learning through the Arts. http:/ / escholarship.org/uc/item/1pd7d6ss?query=Wayang\%20and \%20gamelan\#page-3, accessed 16 July 2014.

- trans. 2011a.

"Ben Go Tun or the Five Rupiah Band by Saini K. M." In The Lontar Anthology of Modern Indonesian Drama, Volume 3: New Directions 1965-1998. Ed. Cobina Gillitt and John McGlynn. Jakarta: Lontar.

2011b.

"Fredrik deBoer." Asian Theatre Journal 28, no. 2: 475-482.

2011c.

“John Emigh." Asian Theatre Journal 28, no. 2: 451-462.

2011d.

"Roger Long." Asian Theatre Journal 28, no. 2: 463-474.

2014a.

Email, 22 July 2014.

2014b.

"Korean Puppetry and Heritage." In Routledge Reader on Puppets in Contemporary Performance. Ed. Dassia Possner, Claudia Orenstein, and John Bell. New York: Routledge.

2014c.

"No More Masterpieces: Tangible Impacts and Intangible Cultural Heritage in Bordered Worlds" Asian Theatre Journal 31, no. 2: 369-398. 2015a.

"Commedia Counterparts: Middle Eastern and Asian Connections." In Routledge Companion to Commedia dell Arte. Ed. Judith Chaffee and Oliver Crick. New York: Routledge.

. 2015b.

Email, 31 March.

trans. 2015c.

"'The Prostitute and the President' by Ratna Sarumpaet." In Islands of the Imagination: Modern Indonesian Plays. Mānoa 26, 2: 175-208. [Also published in Plays by Three Indonesian Women Playwrights (Jakarta: Jakarta Arts Council, 2006), 1-42.] 
$2015 d$.

"Wayang Kelantan beyond Borders." Puppetry International 38 (Fall): 28-31. 2016.

"The Ronggeng, the Wayang, the Wali, and Islam: Female or Transvestite Male Dancers-Singers-Performers and Evolving Islam in West Java." Asian Theatre Journal 32, no. 2: 356-387.

Foley, Kathy, and M. Joshua Karter. 1988.

"Tibetan Opera Music and Dance from Lhasa: An Interview with Dacidan Duoji and Xiaozhaxi Ciren” TDR 32, no. 3: 131-140.

Foley, Kathy, I Ketut Kodi, I Gusti Putu Sudarta, I Nyoman Sedana, and I Made Sidia. 2005.

“Topeng Sidha Karya: A Balinese Mask Dance.” Asian Theatre Journal 22, no. 2: 171-198.

Foley, Kathy, and Nobuko Ochner. 2005.

"Sushin Kani'iri (Possessed by Love, Thwarted by the Bell): A Kumi Odori by Tamagusuku Chokun, as Staged by Kin Ryosho." Trans. Nobuko Ochner with introduction and stage directions by Kathy Foley. Asian Theatre Journal 22, 1: 1-32

Foley, Kathy, and Sabzali Musa Kahn. 2012.

"Staging Raja Tangkai Hati at Istana Budaya: Modernizing Malaysian Mak Yong." Asian Theatre Journal 29, no. 2: 419-436.

Foley, Kathy, and I Nyoman Sedana. 2005.

"Balinese Mask Dance from the Perspective of a Master Artist: I Ketut Kodi on Topeng." Asian Theatre Journal 22, no. 2: 199-213.

Foulc, Thieri de. 2009.

Encyclopédie Mondiale des Arts de la Marionnette. Montpellier: Éditions L'Entretemps.

Jortner, David, and Kathy Foley. 2011.

"James R. Brandon." Asian Theatre Journal 28, no. 2: 342-355.

Leiter, Samuel. 2007.

Encyclopedia of Asian Theatre. Westport, CT: Greenwood Press.

Sedana, I Nyoman. 2014.

Interview, 24 June.

Weintraub, Andrew. 2004.

Power Plays: Wayang Golek Puppet Theatre of West Java. Southeast Asian Studies Series 110. Athens: Ohio University Press.

Wilcox, Emily. 2015.

Email, 21 April. 